Erratum

\title{
Erratum to "Dynamic Shear Properties of Recycled Waste Steel Slag Used as a Geo-Backfill Material"
}

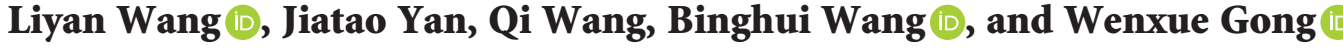 \\ School of Civil and Architectural Engineering, Jiangsu University of Science and Technology, No. 2 Mengxi Road, Zhenjiang, \\ Jiangsu, China \\ Correspondence should be addressed to Liyan Wang; wly_yzu@163.com \\ Received 9 January 2020; Accepted 10 January 2020; Published 8 April 2020 \\ Copyright (C) 2020 Liyan Wang et al. This is an open access article distributed under the Creative Commons Attribution License, \\ which permits unrestricted use, distribution, and reproduction in any medium, provided the original work is properly cited.
}

In the article titled "Dynamic Shear Properties of Recycled Waste Steel Slag Used as a Geo-Backfill Material" [1], there was an error in the author name in reference [24]. The corrected reference is shown below:

[24] L. Y. Wang, S. K. Chen, and P. Gao, "Research on seismic internal forces of geogrids in reinforced soil retaining wall structures under earthquake actions," Journal of Vibroengineering, vol. 16, no. 4, pp. 2023-2034, 2014.

\section{References}

[1] L. Wang, J. Yan, Q. Wang, B. Wang, and A. Ishimwe, "Study on permeability of steel slag and steel slag modifying silt soil as new geo-backfill materials," Advances in Civil Engineering, vol. 2019, Article ID 5370748, 14 pages, 2019. 